\title{
Salicylic Acid Suppresses Potato virus Y Isolate N:O-Induced Symptoms in Tobacco Plants
}

\author{
Xianzhou Nie
}

Potato Research Centre, Agriculture and Agri-Food Canada, P.O. Box 20280, 850 Lincoln Road, Fredericton, New Brunswick, Canada E3B $4 Z 7$. Accepted for publication 14 October 2005.

\begin{abstract}
Nie, X. 2006. Salicylic acid suppresses Potato virus $Y$ isolate N:Oinduced symptoms in tobacco plants. Phytopathology 96:255-263.

The effects of salicylic acid (SA) and 1-aminocyclopropane-1-carboxylic acid (ACC) on the systemic development of symptoms induced by a severe isolate of Potato virus $Y$ group $\mathrm{N}: \mathrm{O}\left(\mathrm{PVY}^{\mathrm{N}: \mathrm{O}}\right)$ in tobacco were investigated. Upon inoculation, the systemic development of symptoms in tobacco plants could be divided into three stages: virus incubation stage, rapid symptom-progress stage, and partial recovery and symptom-shifting stage. Treatment of seedlings with SA delayed the virus-induced necrosis in stems by 1 to 2 days. SA, not ACC, also significantly suppressed the symptom severity in stems. However, neither SA nor ACC treatment affected the partial recovery phenotype exhibited in the latterly emerged

upper parts of the plants. Further analysis indicated that the accumulation of PVY was retarded by SA at the early stage of infection, and the effects were more profound in stems than leaves. Peroxidase (POX) activity and pathogenesis-related (PR) genes $P R-1 a$ and $P R-1 b$ were enhanced by PVY infection. SA not only increased POX activity in stems and PR genes in stems and leaves of mock-inoculated plants, but also elevated the activity of POX in both leaves and stems and the expression of $P R-1 a$ in leaves of PVY-infected plants. Together, the results suggest that systemic acquired resistance plays a key role in suppressing $\mathrm{PVY}^{\mathrm{N}: \mathrm{O}_{\text {-induced }}}$ symptom development through SA-mediated and ethylene-independent pathways. The symptom suppression was correlated with reduced replication/ accumulation of virus at the early stage of infection. The results also suggest that neither SA nor ethylene plays a role in the recovery phenotype.
\end{abstract}

Plant-virus interaction is a complicated process. In a compatible interaction, systemic infection that involves virus multiplication, cell-to-cell movement and long-distance movement takes place, and the host plant exhibits a susceptible phenotype (13). In an incompatible reaction, systemic infection is disrupted, and the host plant demonstrates a resistant phenotype (13). Incompatible reactions are typically controlled by resistance $(R)$ genes, and the resistance is virus species- and/or strain-specific (22). Besides the $R$ gene (including the $N$ gene) mediated resistance, systemic acquired resistance (SAR) which is inducible and pathogen-nonspecific has been recognized $(10,37,43)$. SAR is generally coupled with elevated expression of pathogenesis-related (PR) genes (10, 43). In addition, reactive oxygen species (ROS) and associated enzymes also play a role in SAR $(5,37)$.

Salicylic acid (SA) has been shown to be involved in responses to pathogen attack in various plant species. It appears that the induction of SA is essential in resistant responses against viruses, fungi, and bacteria $(25,37)$. Depletion of SA by introducing SA hydroxylase $(n a h G)$ in tobacco plants results in the loss of $N$ gene-mediated resistance against Tobacco mosaic virus (TMV) (6). Pretreatment of susceptible tobacco plants or plant tissues with SA or a SA derivative, aspirin, leads to a significant reduction in accumulation of TMV $(1,47)$ and TMV RNA (7). The treatment also results in delays of systemic development of TMVinduced symptoms (32). Similarly, SA delays the Potato virus $X$ (PVX) as well as the Cucumber mosaic virus (CMV)-induced symptoms in tobacco and Arabidopsis plants $(23,27)$. In addition to SA, many other signal molecules including ethylene, NO, and

Corresponding author: X. Nie; E-mail address: niex@agr.gc.ca

* The $e$-Xtra logo stands for "electronic extra" and indicates that the abstract available online contains supplemental material not included in the print edition. Figures 1 and 2 are in color online.

DOI: 10.1094/PHYTO-96-0255

(C) 2006 The American Phytopathological Society
$\mathrm{H}_{2} \mathrm{O}_{2}$ are also involved in SAR in many different plant species $(28,43,44)$.

Potato virus $Y$ (PVY), genus Potyvirus, is a single-strand, positive RNA virus that induces severe symptoms in potato and tobacco plants (40). Multiple strains and substrains including common strain $\left(\mathrm{PVY}^{\mathrm{O}}\right)$, tobacco veinal necrosis strain $\left(\mathrm{PVY}^{\mathrm{N}}\right)$, and potato tuber necrosis substrain (PVY ${ }^{\mathrm{NTN}}$ ) exist. Recently, a recombinant isolate group, $\mathrm{PVY} \mathrm{Y}^{\mathrm{N}: \mathrm{O}}$, whose genome comprises segments of $P V Y^{\mathrm{O}}$ and $P V Y^{\mathrm{N}}$, has been identified $(14,30,42)$. Like $\mathrm{PVY}^{\mathrm{N}}$ and PVY ${ }^{\mathrm{NTN}}, \mathrm{PVY}^{\mathrm{N}: \mathrm{O}}$ induces vein clearing, veinal necrosis, foliar deformation and stem necrosis in tobacco plants (30). Since its discovery in the mid-1980s (8), the isolate group has been widely reported in Europe and North America $(14,34,42)$. The spread of PVY ${ }^{\mathrm{N}: \mathrm{O}}$ in North America is at least partially due to its indistinguishable serological property from $\mathrm{PVY}^{\mathrm{O}}$, and thus evading the serological indexing used in potato seed certification system (42).

Genomic analysis of PVY ${ }^{\mathrm{N}: \mathrm{O}}$ structure demonstrates that the genome portion (nucleotide 1 to approximately 2,400) derived from $\mathrm{PVY}^{\mathrm{N}}$ might play a key role in its pathogenicity in tobacco plants (30). However, little is known about how tobacco plants respond to infections by the virus. Transgenic tobacco plants expressing cell wall invertase exhibit elevated $P R-Q$ expression and lesions in leaves $(16,17)$. These plants are $\mathrm{PVY}^{\mathrm{N}}$-resistant, and the resistance appears to be sugar mediated and salicylate independent (17). Meanwhile, resistance against $P V Y^{\mathrm{N}}$ conferred by recessive $R$ genes has been reported in tobacco, tomato, and pepper $(3,22,33)$; however, the resistance can be overcome as the virus mutates (22).

In this study, the effects of SA and 1-aminocyclopropane-1-carboxylic acid (ACC), a precursor of ethylene biosynthesis, on $\mathrm{PVY}^{\mathrm{N}: \mathrm{O}}$-induced systemic development of symptoms in tobacco plants were investigated. The results demonstrate that SA, not ACC, delayed symptom development and alleviated symptom severity in stems of tobacco plants challenged with PVY. The suppression of symptoms by SA was correlated with reduced replica- 
tion/accumulation of $\mathrm{PVY}^{\mathrm{N}: \mathrm{O}}$, and was associated with elevated peroxidase (POX) activity and PR gene expression. This is, apparently, the first time that salicylate-mediated SAR against a potyvirus is demonstrated.

\section{MATERIALS AND METHODS}

Virus isolate and tobacco plants. $\mathrm{PVY}^{\mathrm{N}: \mathrm{O}} \mathrm{Mb} 58$ was obtained from Manitoba, Canada (30), and was used to inoculate Nicotiana tabacum cv. Samsun plants.

Inoculation of $\boldsymbol{N}$. tabacum cv. Samsun plants. Five fully expanded leaves $(\approx 15 \mathrm{~g})$ of $\mathrm{PVY}^{\mathrm{N}: \mathrm{O}}$ Mb58-infected tobacco plants were homogenized in $50 \mathrm{ml}$ of inoculation buffer $(10 \mathrm{mM}$ sodium phosphate buffer, pH 7.5, with $32 \mathrm{mM} \mathrm{Na} \mathrm{SO}_{3}$ ) and filtered through double-layer cheese cloth. The extract was then used to inoculate 'Samsun' seedlings. Briefly, tobacco seedlings at fiveleaf stage were dusted with Carborundum, and the top three leaves were rubbed gently with a pestle in the presence of $0.73 \mathrm{ml}$ of virus extract or inoculation buffer (mock) per leaf. The plants were then maintained in the greenhouse with a light/dark cycle of $16 / 8 \mathrm{~h}$ at 18 to $24^{\circ} \mathrm{C}$. The humidity in the greenhouse was 50 to $70 \%$, and the sunlight was supplemented with artificial light. The symptom expression was recorded from day one up to 30 days postinoculation (dpi).

Treatments with SA and ACC. Tobacco seedlings were sprayed twice per day with various concentrations of SA ( $\mathrm{pH} 7.0$ ) or ACC solution containing 2 drops/liter Tween 20, started 3 days prior to inoculation and lasted as long as the plants were kept.

Enzyme activity measurements. Freshly sampled leaves and stem cortexes (including epidermises) were immediately frozen in liquid nitrogen and stored at $-80^{\circ} \mathrm{C}$. POX (EC 1.11.1.7) activity was measured based on the procedure described by Shetty et al. (38) with some modifications. Briefly, $0.3 \mathrm{~g}$ of frozen tissue was homogenized in $3 \mathrm{ml}$ of ice-cold extraction buffer $(50 \mathrm{mM}$ potassium acetate, $\mathrm{pH} 5.2,100 \mathrm{mM} \mathrm{KCl}, 1 \mathrm{M} \mathrm{NaCl}, 1 \mathrm{mM} \mathrm{CaCl}_{2}$, and $1 \mathrm{mM}$ ascorbic acid) using a Polytron (Kinematica $\mathrm{GmbH}$, Kriens-Luzern, Switzerland) for $30 \mathrm{~s}$. The solution was centrifuged at $12,000 \times g$ for $12 \mathrm{~min}$ at $4^{\circ} \mathrm{C}$. The supernatant was transferred to a $1.5-\mathrm{ml}$ microtube and placed on ice. The enzyme activity was monitored spectrophotometrically at $20^{\circ} \mathrm{C}$ using 8453 UV-Visible Spectrophotometer (Agilent Technologies, Palo Alto, $\mathrm{CA}$ ). To $1 \mathrm{ml}$ of substrate solution containing $100 \mathrm{mM}$ sodium acetate, pH 5.5, $360 \mu \mathrm{M}$ 2,2'-azino-bis(3-ethylbenzthiazoline-6sulfonic acid) (ABTS), and $0.63 \mathrm{mM} \mathrm{H}_{2} \mathrm{O}_{2}, 10 \mu \mathrm{l}$ of enzyme extract was added and mixed. The absorbance at $405 \mathrm{~nm}\left(A_{405}\right)$ was recorded every $10 \mathrm{~s}$ for $4 \mathrm{~min}$. The change of $A_{405}$ versus time was plotted, and the linear portion was used to calculate the enzyme activity, which was expressed as $A_{405} \mathrm{mg}$ protein ${ }^{-1} \mathrm{~min}^{-1}$.

Catalase (CAT, EC 1.11.1.6) activity was measured according to the procedure described by Havir and McHale (15) with slight modifications. Crude enzyme was isolated by grinding $0.3 \mathrm{~g}$ of frozen tissue with $3 \mathrm{ml}$ of extraction buffer $(0.05 \mathrm{M}$ potassium phosphate buffer, $\mathrm{pH} 7.5,6.5 \mathrm{mM}$ dithiothreitol [DTT]) on ice using a Polytron for $30 \mathrm{~s}$. The solution was centrifuged at 13,500 $\times \mathrm{g}$ for $15 \mathrm{~min}$ at $4^{\circ} \mathrm{C}$. The supernatant was transferred to a $1.5-\mathrm{ml}$ microtube and kept on ice. The activity of CAT was measured by monitoring the $\mathrm{H}_{2} \mathrm{O}_{2}$ change during the course of reaction. Briefly, to $1 \mathrm{ml}$ of substrate buffer containing $30 \mathrm{mM} \mathrm{H}_{2} \mathrm{O}_{2}$ and $50 \mathrm{mM}$ potassium phosphate buffer, $\mathrm{pH} 7.0,50 \mu \mathrm{l}$ of enzyme was added. The absorbance at $240 \mathrm{~nm}\left(A_{240}\right)$ was monitored continuously for $4 \mathrm{~min}$ at $30^{\circ} \mathrm{C}$, taking reading every $10 \mathrm{~s}$ using the kinetics mode of the 8453 UV-Visible Spectrophotometer (Agilent Technologies). The activity was expressed as $A_{240} \mathrm{mg}$ protein ${ }^{-1}$. $\mathrm{min}^{-1}$.

Protein assay. Protein was measured using the Bradford assay (2) and bovine serum albumin as the standard.

PVY level and gene expression analysis. Semiquantitative reverse transcription-polymerase chain reaction (RT-PCR) was used to assess the virus level and gene expression. Total RNA from leaf or stem cortex was isolated as described previously $(24,29)$. The RNA was then incubated with RNase-free DNase I (Roche Diagnostics, Indianapolis, IN) at $37^{\circ} \mathrm{C}$ for $10 \mathrm{~min}$. Thereafter, the solution was extracted with water-saturated phenol once, phenol/ chloroform/isoamyl alcohol (25:24:1, vol/vol/vol) once, and chloroform/isoamyl alcohol (24:1, vol/vol) once. Total RNA was precipitated by adding 2 volumes of $95 \%$ ethanol at $-20^{\circ} \mathrm{C}$ for $2 \mathrm{~h}$, recovered by centrifugation at $12,000 \times g$ for $20 \mathrm{~min}$ at $4^{\circ} \mathrm{C}$, and quantified with a spectrophotometer (GeneQuant, Biochem, $\mathrm{UK})$.

RT was carried out using random primers as described previously $(29,31)$. Briefly, $1 \mu \mathrm{g}$ of total RNA in $2.5 \mu \mathrm{l}$ was mixed with $1 \mu \mathrm{l}(1 \mu \mathrm{g})$ of hexanucleotides (Roche Diagnostics), incubated at $68^{\circ} \mathrm{C}$ for $8 \mathrm{~min}$, and chilled on ice for $3 \mathrm{~min}$. A total of $6.5 \mu \mathrm{l}$ of the RT mixture was added to provide a final concentration of $50 \mathrm{mM}$ Tris- $\mathrm{HCl}, \mathrm{pH} 8.3,75 \mathrm{mM} \mathrm{KCl}, 10 \mathrm{mM}$ DTT, $2.5 \mathrm{mM}$ $\mathrm{MgCl}_{2}, 1.0 \mathrm{mM}$ of each dNTP (dATP, dTTP, dCTP, and dGTP), 5 units of RNasin Ribonuclease Inhibitor (Promega Corp., Madison, WI), and 100 units of Moloney murine leukemia virus reverse transcriptase (Promega). Samples were incubated at $42^{\circ} \mathrm{C}$ for $1 \mathrm{~h}$ and at $95^{\circ} \mathrm{C}$ for $2 \mathrm{~min}$. Thereafter, $40 \mu \mathrm{l}$ of $\mathrm{H}_{2} \mathrm{O}$ was added to the cDNA mix, and the resulting cDNA solution was used for semiquantitative PCR analysis of PVY level and gene expression.

Duplex PCR that included two pairs of primers, one targeting the cytochrome c oxidase subunit 1 (COX1), a control gene (29, 31 ), and the other targeting the gene of interest, was performed. The primers for COXI (accession no. BA000042), 5'CTAATTCTGGGCTAGACATTGC3' and 5'CTTCACATAGCTTTTCGT$\mathrm{CTCC}^{\prime}$, produced a fragment of $500 \mathrm{bp}$; the primers for $P R-1 a$ (accession no. X06930), 5'CGACCTACGTCCATTTCACG3' and 5'GCAAGTAGCTAGACCATCAAC3', produced a fragment of $266 \mathrm{bp}$; the primers for $P R-1 b$ (accession no. X66942), 5'TAATAACGGTTTACGTGATCA3' and 5'TGACTCATCACCTTGTTCACT3', produced a fragment of $244 \mathrm{bp}$; and the primers for PVY (41), 5'ACGTCCAAAATGAGAATGCC3' and 5'TGGTGTTCGTGATGTGACCT3', produced a fragment of $480 \mathrm{bp}$. The amplification was conducted in a volume of $25 \mu \mathrm{l}$ containing $4-\mu \mathrm{l}$ aliquots of the cDNA mixture, $10 \mathrm{mM}$ Tris- $\mathrm{HCl}, \mathrm{pH} 8.3,50 \mathrm{mM}$ $\mathrm{KCl}, 1.5 \mathrm{mM} \mathrm{MgCl} 2,100 \mu \mathrm{M}$ each of dNTPs (Promega), $0.1 \mu \mathrm{g}$ each of the sense and antisense primers, and 0.625 units of Taq polymerase (PE Applied Biosystems, Foster City, CA). Samples were amplified in 10, 15, and 20 cycles using a PTC-200 Thermocycler (MJ Research, Watertown, MA) with DNA denaturing at $92^{\circ} \mathrm{C}$, primer annealing at 60 to $55^{\circ} \mathrm{C}(30)$, and primer extension at $72^{\circ} \mathrm{C}$, each for $45 \mathrm{~s}$. A final step of $10 \mathrm{~min}$ at $72^{\circ} \mathrm{C}$ was also included. A total of $10 \mu \mathrm{l}$ of the amplification product was fractionated by electrophoresis on $1.5 \%$ agarose gel containing $0.5 \mu \mathrm{g} / \mathrm{ml}$ ethidium bromide and photographed under UV illumination. A low mass DNA ladder (Gibco-BRL, Gaithersburg, MD) was used in the gel to determine the size of the amplified products. After the electrophoresis, the gel was blotted to Hybond-N+ (Amersham Biosciences, Piscataway, $\mathrm{NJ}$ ) according to the manufacturer's instructions, and the resulting membrane was hybridized with probes corresponding to the gene of interest. Briefly, PCR amplification fragment of the gene of interest was extracted from agarose gel and used as template for labeling with the Gene Images AlkPhos Direct Labeling and Detection System (Amersham Biosciences) according to the manufacturer's instructions. After hybridization, the membrane was washed to remove the excess probe and incubated with the CDP-star chemiluminescent detection reagents (Amersham Biosciences). The chemiluminescent signals were detected by exposure of X-ray film (X-AR, Kodak) at room temperature.

\section{RESULTS}

Symptom development in N. tabacum cv. Samsun upon inoculation with $\mathbf{P V Y}^{\mathrm{N}: O}$. Vein clearing in the newly emerged 
leaves was the first visible response, which occurred approximately $7 \mathrm{dpi}$. At 7 to $8 \mathrm{dpi}$, necrosis appeared at the junctions of stem and petioles of leaves showing vein clearing; and at 8 to 9 dpi, isolated necrotic spots occurred in stem segment stretching from the bottom of the stem to three to four nodes above the inoculated leaves. At 10 to $14 \mathrm{dpi}$, rapid progress of necrosis took place in petioles of leaves showing vein netting and clearing and stem section ranging from bottom to three to four nodes above the inoculated leaves (Fig. 1A). Foliar distortion also occurred in these leaves. Concurrently, milder symptoms (mosaic, mottling, and mild leaf distortion) were observed in latterly emerged leaves, and no necrosis occurred in the petioles of these leaves and the stem sections where these leaves were located (Fig. 1A and B). The phenomenon resembled the recovery phenotype described in several virus-host systems $(11,35,36)$. However, unlike the typical recovery in those systems, distinct mottling in the latterly emerged leaves became apparent as the leaves aged (Fig. 1A), indicating that the "recovery" was partial. Based on these observations, the interaction between PVY ${ }^{\mathrm{N}: \mathrm{O}}$ and tobacco plants could be divided into three stages, i.e., virus incubation stage (from inocu- lation to $\approx 7 \mathrm{dpi}$ ), rapid symptom-progress stage ( 8 to $14 \mathrm{dpi}$ ), and partial recovery and symptom-shifting stage ( $\approx 15 \mathrm{dpi}$ and later).

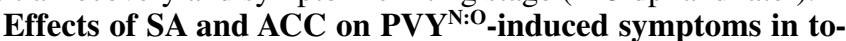
bacco. Symptoms were recorded and scored based on the degree of stem necrosis and number of nodes/internodes that the necrosis stretched. A higher degree of symptom severity indicates more necrotic spots and each spot covers a larger area. As shown in Table 1 , at 14 dpi, SA reduced PVY-induced symptoms by alleviating the degree of stem necrosis and the number of nodes/internodes that exhibited necrosis. The suppression became evident once the SA concentration increased to $1 \mathrm{mM}$. When SA concentration increased further to $5 \mathrm{mM}$, the degree of stem necrosis reduced by $50 \%$ and the symptom severity was approximately one-third of that of control (Table 1). However, plants treated with $5 \mathrm{mM} \mathrm{SA}$ exhibited a retarded growth rate and reduced leaf sizes in both PVY-inoculated and mock-inoculated plants (data not shown). To minimize these side effects, $1 \mathrm{mM} \mathrm{SA}$ was selected for further experiments.

SA delayed necrotic symptom initiation and development in stems by 1 to 2 days. At $10 \mathrm{dpi}$, light patchy necrosis (degree of

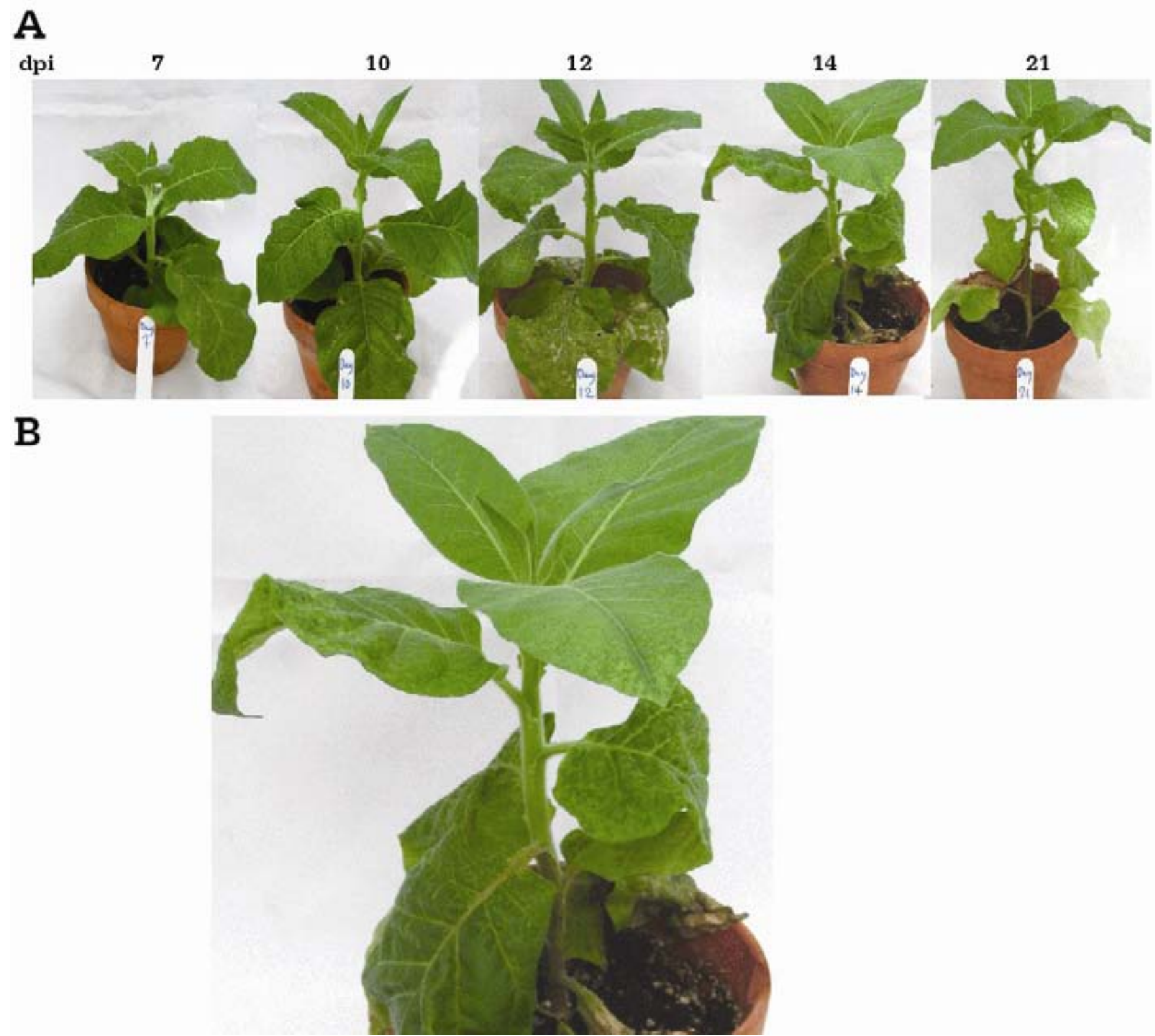

Fig. 1. Systemic development of symptoms induced by Potato virus $Y$ isolate N:O (PVY $\left.{ }^{\mathrm{N}: O}\right)$ Mb58 in tobacco plants. Tobacco cv. Samsun seedlings were mechanically inoculated with PVY ${ }^{\mathrm{N}: \mathrm{O}}$ Mb58 and kept in the greenhouse for symptom development. A, Symptoms in plants at various days postinoculation (dpi). $\mathbf{B}$, Enlarged picture of a plant at 14 dpi demonstrating the reduced symptoms in the upper part. 
stem necrosis: 3 to 4 ) occurred on stems of water-treated plants, whereas one to two light necrotic spots (degree of stem necrosis: 1 to 2) were observed on stems of SA-treated plants (Fig. 2A and B). At 14 dpi, significant necrosis (degree of stem necrosis: 5 to

TABLE 1. Effects of various concentrations of salicylic acid (SA) and 1aminocyclopropane-1-carboxylic acid (ACC) on symptom severity in tobacco plants inoculated with Potato virus $Y\left(\mathrm{PVY}^{\mathrm{N}: \mathrm{O}}\right)$ at 14 days postinoculation ${ }^{\mathrm{a}}$

\begin{tabular}{|c|c|c|c|}
\hline \multirow[b]{2}{*}{ Treatment } & \multicolumn{2}{|c|}{ Stem necrosis } & \multirow{2}{*}{$\begin{array}{c}\text { Score of } \\
\text { symptom severity }\end{array}$} \\
\hline & Degree of necrosis & Number of nodes & \\
\hline \multicolumn{4}{|l|}{$\mathrm{SA}(\mathrm{mM})$} \\
\hline 0.0 & $7.00 \pm 1.90$ & $5.70 \pm 0.75$ & $41.10 \pm 16.23$ \\
\hline 0.1 & $6.00 \pm 1.97$ & $4.90 \pm 0.66$ & $30.35 \pm 14.01$ \\
\hline 1.0 & $6.00 \pm 2.30$ & $4.40 \pm 1.02$ & $24.30 \pm 12.42$ \\
\hline 5.0 & $3.00 \pm 1.70$ & $3.60 \pm 2.06$ & $14.10 \pm 9.58$ \\
\hline \multicolumn{4}{|l|}{$\operatorname{ACC}(\mu \mathrm{M})$} \\
\hline 0.0 & $7.80 \pm 1.12$ & $5.20 \pm 0.75$ & $40.90 \pm 9.03$ \\
\hline 10.0 & $5.75 \pm 2.51$ & $5.10 \pm 0.73$ & $39.25 \pm 11.89$ \\
\hline 50.0 & $8.00 \pm 0.87$ & $6.10 \pm 1.11$ & $47.80 \pm 13.79$ \\
\hline
\end{tabular}

a The data shown are means \pm standard deviations of four replicates from one of the three repeats of the experiment. The degree of necrosis was based on the area and color of the necrosis on stems ( 0 , no necrosis; 1 to 2 , one to two necrotic spots; 3 to 4 , light patchy necrosis; 5 to 6 , dark patchy necrosis; 7 to 8 , heavy dark necrosis on one side of the stem or dark patchy necrosis around the stem; and 9 to 10 , heavy dark necrosis around the stem). The score of symptom severity was obtained by multiplying degree of necrosis and number of nodes exhibiting necrosis.
8) was observed in water-treated plants, and light patchy necrosis (degree of stem necrosis: 3 to 4 ) occurred in SA-treated plants (Fig. 2B). The suppressive effects of SA on symptom development in stems became more evident at a later stage when the necrotic tissue, mainly the epidermis, darkened and became dead (Fig. 2). Unlike that in stems, symptoms in leaves did not appear to be significantly affected by SA treatment. In addition, SA treatment neither altered the overall symptom patterns nor affected the partial recovery and symptom-shifting in the plants.

Exogenous ACC did not affect PVY-induced symptom development and severity. No differences were observed among plants treated with 0 to $50 \mu \mathrm{M}$ ACC in terms of degree of stem necrosis, number of nodes/internodes that exhibited necrosis, and the overall symptom severity (Table 1), suggesting that ethylene does not affect PVY ${ }^{\mathrm{N}: \mathrm{O}}$-induced systemic development of symptoms in tobacco. Like SA, exogenous ACC did not affect the symptom patterns or the partial recovery in the plants.

Effects of $\mathrm{SA}$ on replication of $P V Y^{\mathrm{N}: O}$ in tobacco plants. The relative amount of PVY was monitored in plants treated with various concentrations of SA at 6 dpi. As the concentration of SA increased, a relatively lower level of PVY was found in both leaves and stems, and this became more profound when SA concentration reached $1 \mathrm{mM}$ (Fig. 3A). However, at $5 \mathrm{mM}$, SA not only lowered PVY levels but also interfered with the expression of $C O X 1$, a mitochondrial encoded gene, indicating nonspecific inhibitory effects of SA on plants at this concentration, coincided
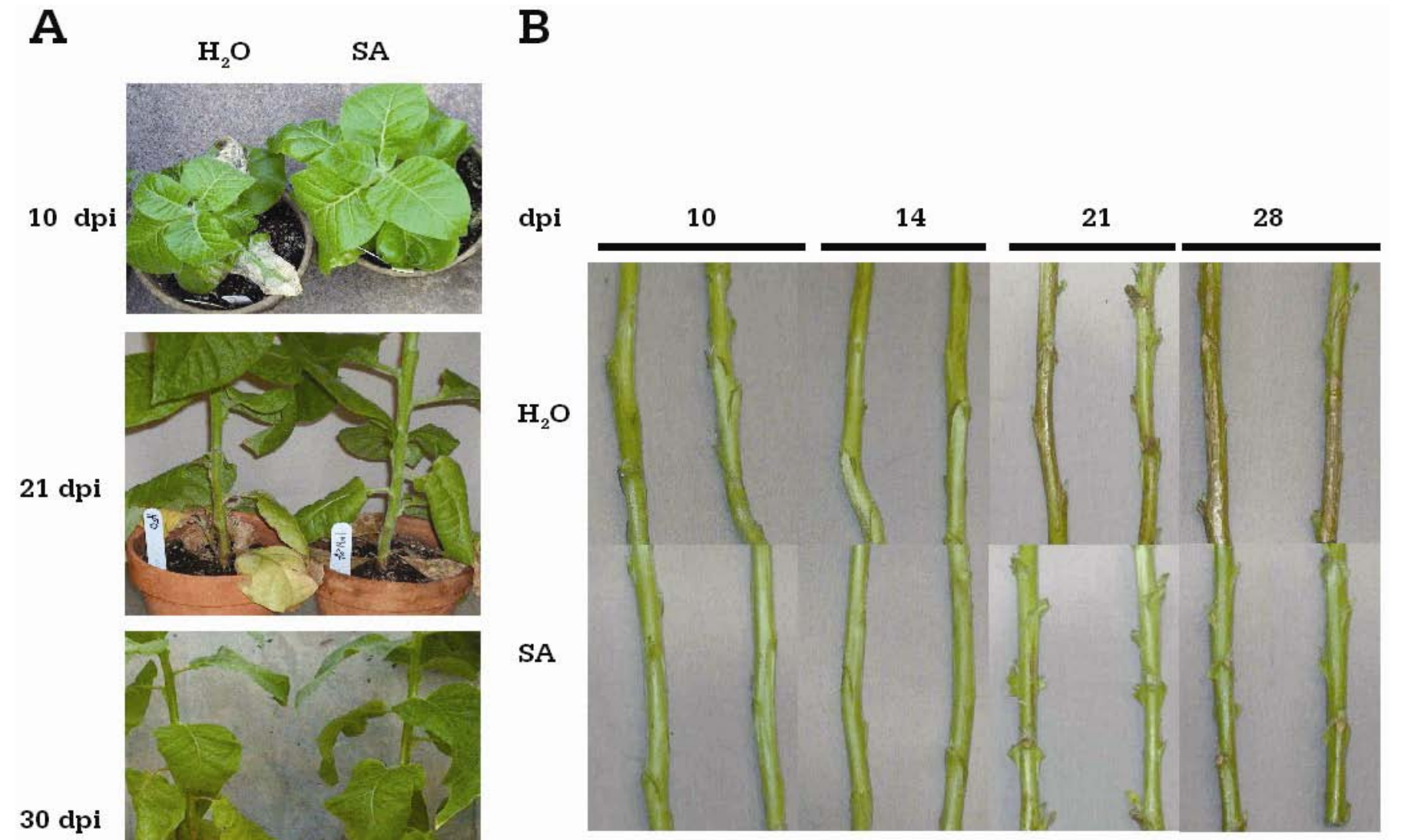

30 dpi

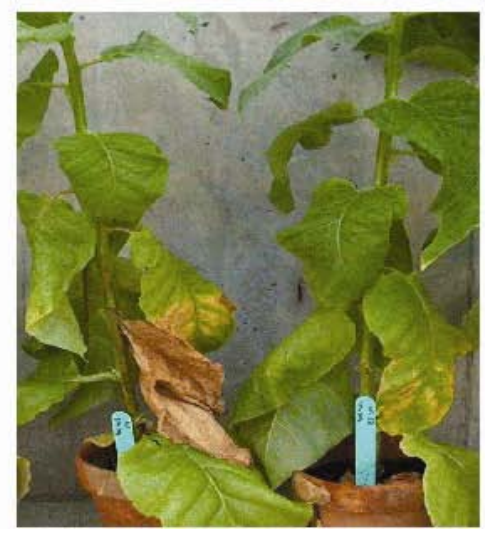

SA

Fig. 2. Effects of salicylic acid (SA) on Potato virus $Y$ isolate $\mathrm{N}: \mathrm{O}\left(\mathrm{PVY}^{\mathrm{N}: O}\right)$ Mb58 induced systemic development of symptoms in tobacco plants. Tobacco cv. Samsun seedlings were sprayed with $1 \mathrm{mM} \mathrm{SA}$ or $\mathrm{H}_{2} \mathrm{O} 3$ days prior to mechanical inoculation with the virus, and were sprayed continuously in the greenhouse until sampled. A, Whole plants at various days postinoculation (dpi). B, Stem segments from plants treated with water or $1 \mathrm{mM} \mathrm{SA} \mathrm{at} \mathrm{various} \mathrm{dpi.}$ 
with the visual observation of tobacco plants treated with $5 \mathrm{mM}$ SA. The effect of $1 \mathrm{mM}$ SA on PVY accumulation/replication/ transportation was further examined during the virus incubation stage and rapid symptom-progress stage, i.e., 0 to 14 dpi. As shown in Figure 3B, PVY became detectable in the growing leaves at $4 \mathrm{dpi}$ and in stems at $2 \mathrm{dpi}$ in both SA-treated and untreated $\left(\mathrm{H}_{2} \mathrm{O}\right.$-treated $)$ plants. From 4 to $7 \mathrm{dpi}$, virus concentration increased dramatically in both stems and leaves, and thereafter, the concentration remained similar. In leaves, PVY accumulation was slightly retarded by SA treatment before 7 dpi; afterward, the virus reached the similar level in both SA-treated and untreated plants. In stems, lower levels of PVY were found in SA-treated plants than in untreated plants from 2 to $8 \mathrm{dpi}$, and thereafter, similar levels of PVY were observed in both treated and untreated plants (Fig. 3B), indicating that SA interferes with the replication/transportation of PVY in tobacco plants, especially in stems.

Effects of SA on activities of POX and CAT in PVY ${ }^{\mathrm{N}: O}$-challenged tobacco plants. To reveal the possible involvement of ROS-associated enzymes in PVY-tobacco interaction, activities of POX and CAT were monitored in both SA-treated and untreated plants after inoculation with PVY. At 14 dpi, a higher POX activity was observed in plants treated with SA compared with those in water control $(0 \mathrm{mM})$ (Fig. 4). The increment of activity in the treated plants was associated with SA concentration: as SA concentration increased from 0 to $5 \mathrm{mM}$, POX activity increased approximately threefold (from $\approx 98$ to $\approx 300$ ) in leaves and $\approx 35 \%$ (from $\approx 750$ to $\approx 1,000$ ) in stems. In leaves, $\approx 20 \%$ increase of CAT activity was observed once the SA concentration reached $1 \mathrm{mM}$; and $5 \mathrm{mM}$ SA did not further increase the activity of CAT. In stems, no difference was observed between 0 and $0.1 \mathrm{mM}$ SA on CAT activity, whereas $1 \mathrm{mM}$ SA treatment resulted in a decreased enzyme activity level, and as SA concentration increased to $5 \mathrm{mM}$, a higher CAT activity was observed.

To further explore the dynamics of POX and CAT in plants during the course of PVY-tobacco interaction, the activities of these two enzymes were measured during the phase of rapid progress of symptoms, i.e., from 7 to $14 \mathrm{dpi}$. In mock-inoculated plants, a higher POX activity was observed in stems of SA-treated over untreated $\left(\mathrm{H}_{2} \mathrm{O}\right.$-treated) plants, indicating the inductive effects of SA on POX in the tissue (Fig. 5). Infection of PVY resulted in elevated POX activity in both leaves and stems. As disease progressed, the activity of POX increased in both SA-treated and untreated plants, indicating the induction of POX by PVY. From 7 to 12 dpi, a significantly higher POX activity was recorded in SAtreated plants compared with untreated plants, and at $14 \mathrm{dpi}$, the difference of POX activity between the treated and untreated plants decreased. CAT activity exhibited a relatively small change in plants over the period of rapid symptom development (Fig. 5). Although CAT activity was slightly higher in SA-treated plants than in untreated mock-inoculated plants, the difference was not significant. In leaves, SA-treated plants demonstrated a higher CAT activity than untreated plants at 7 and $10 \mathrm{dpi}$, and the difference diminished once it reached $12 \mathrm{dpi}$. Thereafter, the activity in both treated and untreated plants decreased. In stem, slightly higher activity was recorded in SA-treated plants at $7 \mathrm{dpi}$ in both mock- and PVY-inoculated plants. However, as disease progressed, CAT activity in untreated plants surpassed the treated plants and peaked at 10 to $12 \mathrm{dpi}$. Thereafter, the activity in both SA-treated and untreated plants decreased.

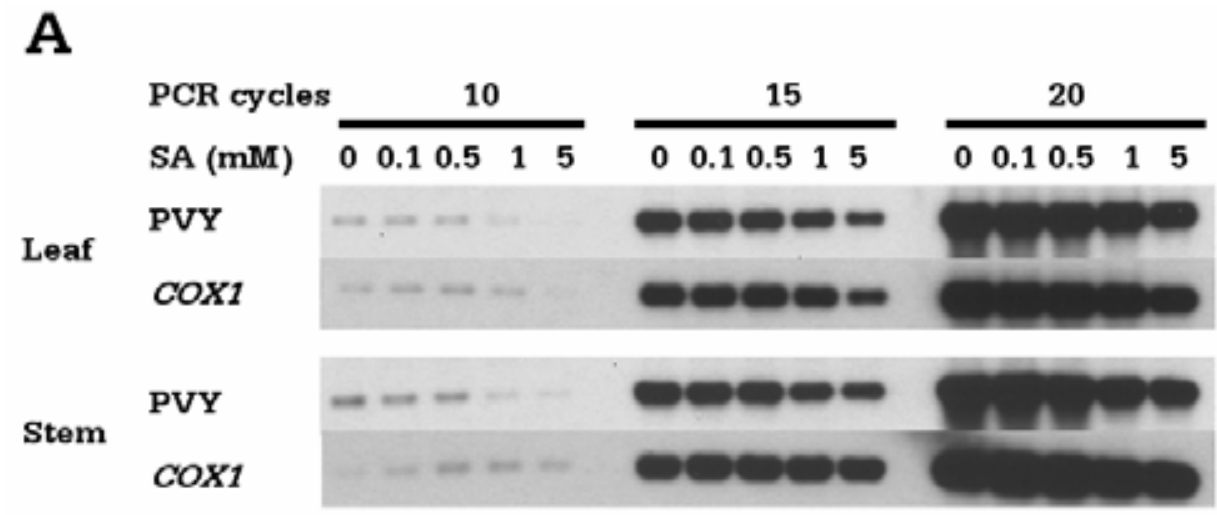

B
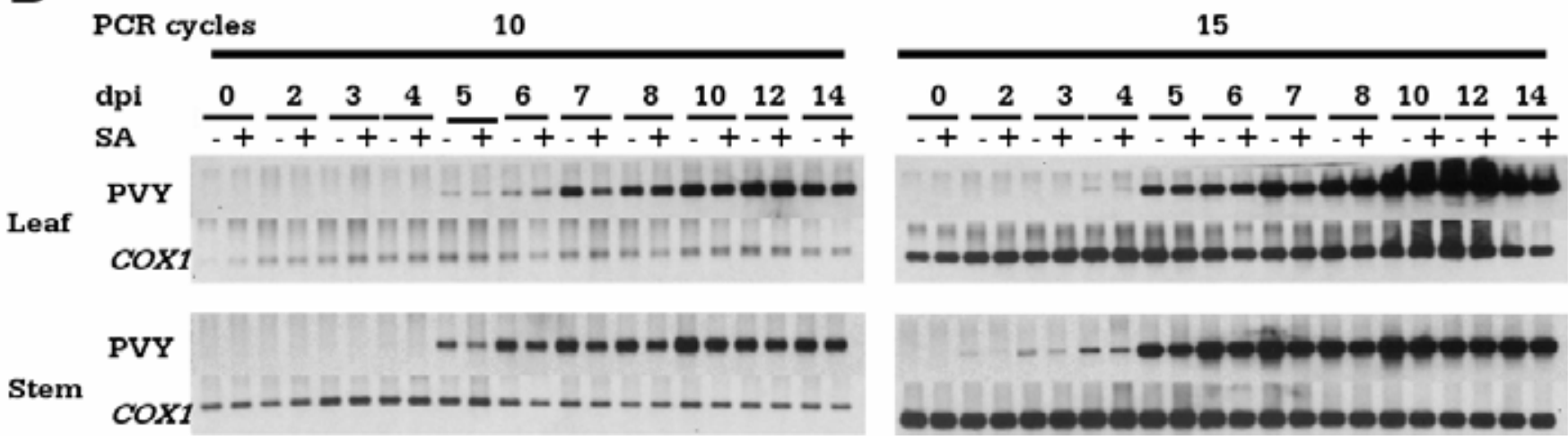

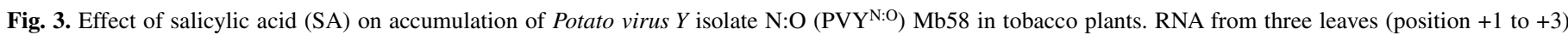

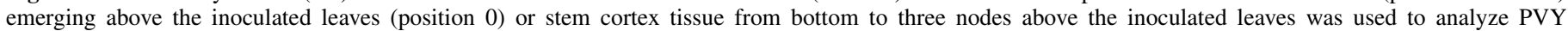

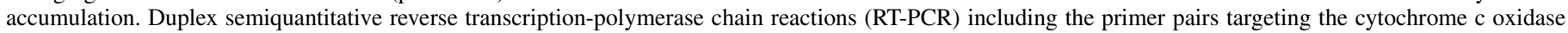

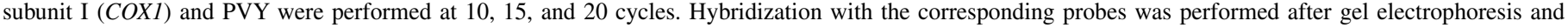

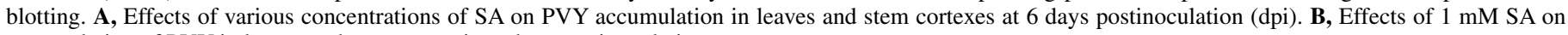
accumulation of PVY in leaves and stems at various days postinoculations. 
Effects of SA on PR gene expression in PVY ${ }^{\mathrm{N}: \mathrm{O}}$-challenged tobacco plants. The expression of PR genes, represented by $P R$ $l a$ and $P R-1 b$, were studied at the rapid symptom-progress stage. In mock-inoculated plants, the expression of both genes was higher in SA-treated than in untreated $\left(\mathrm{H}_{2} \mathrm{O}\right.$-treated) plants (Fig. 6 ), indicating the inductive effects of SA on these genes. Infection of tobacco plants by $\mathrm{PVY}^{\mathrm{N}: \mathrm{O}}$ led to elevated expression of $P R-1 a$ and $P R-1 b$ in both SA-treated and untreated plants. And, except $P R-1 b$ in SA-treated plants, the expression of the genes increased as the disease progressed (Fig. 6), whereas PVY level did not change significantly during the time span (Figs. 3B and 6). SA augmented PR-1a expression in leaves of PVY-infected plants; however, an opposite trend was observed in stems. The compound did not appear to alter the expression of $P R-1 b$ in both leaf and stem cortex tissues of PVY-infected plants during the time course.

\section{DISCUSSION}

Examination of the systemic infection by $\mathrm{PVY}^{\mathrm{N}: \mathrm{O}}$ and disease development in tobacco cv. Samsun plants indicates that the infection/disease development can be divided into three stages: virus incubation stage, rapid symptom-progress stage, and partial recovery and symptom-shifting stage. The incubation stage was characterized by rapid accumulation of PVY without visible symptoms in the plants (Figs. 1 and 3). The second stage was symbolized by rapid progress of symptoms that included veinal, petiole, and stem necrosis, and leaf malformation (Fig. 1). The partial recovery and symptom-shifting stage was characterized by milder symptoms in the latterly emerged leaves and stems (Fig. 1). It is noteworthy that severe necrotic symptoms were only limited to certain leaves and areas of stem during the course of

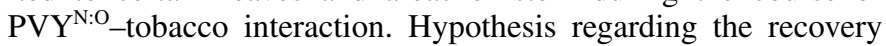
phenotype has been elucidated in various virus-host systems $(21,35,36)$, and virus-induced gene silencing (VIGS) has been demonstrated to play a key role in the process $(35,36)$. It is possible that initial infection of $\mathrm{PVY}^{\mathrm{N}: \mathrm{O}}$ on tobacco cv. Samsun plants might have triggered the VIGS-like responses in latterly emerging leaves and stems, and thus alleviated the symptom severity. However, it is unclear whether the VIGS-like process is the exclusive mechanism that might be involved in the partial recovery and symptom attenuation in the upper part of $\mathrm{PVY}^{\mathrm{N}: \mathrm{O}}$-challenged plants. Nevertheless, the failure of exogenous SA and ACC to alter the overall symptoms patterns or to affect the recovery process during the course of $\mathrm{PVY}^{\mathrm{N}: \mathrm{O}}$-tobacco interaction suggests that the signals lead to partial recovery and symptom-shifting is independent from SA and ethylene.

SAR is characterized by its inductive nature by a wide range of chemicals and stimuli including microbe invasions $(9,12,37,39$, 43). Unlike resistance mediated by $R$ gene and/or RNA silencing, SAR is not pathogen specific $(37,43)$. SA plays a key role in SAR in many plant species against various pathogens including fungi, bacteria, and viruses (37), and plant growth regulators such as jasmonic acid and ethylene have also been shown to be involved in the signaling pathways of SAR $(9,39)$. When applied to tobacco cv. Samsun plants, SA at a concentration of 1 to $5 \mathrm{mM}$ significantly reduced $\mathrm{PVY} \mathrm{N}^{\mathrm{N}}$-induced necrosis in stems, whereas the ethylene precursor ACC did not show any effects on the symptom
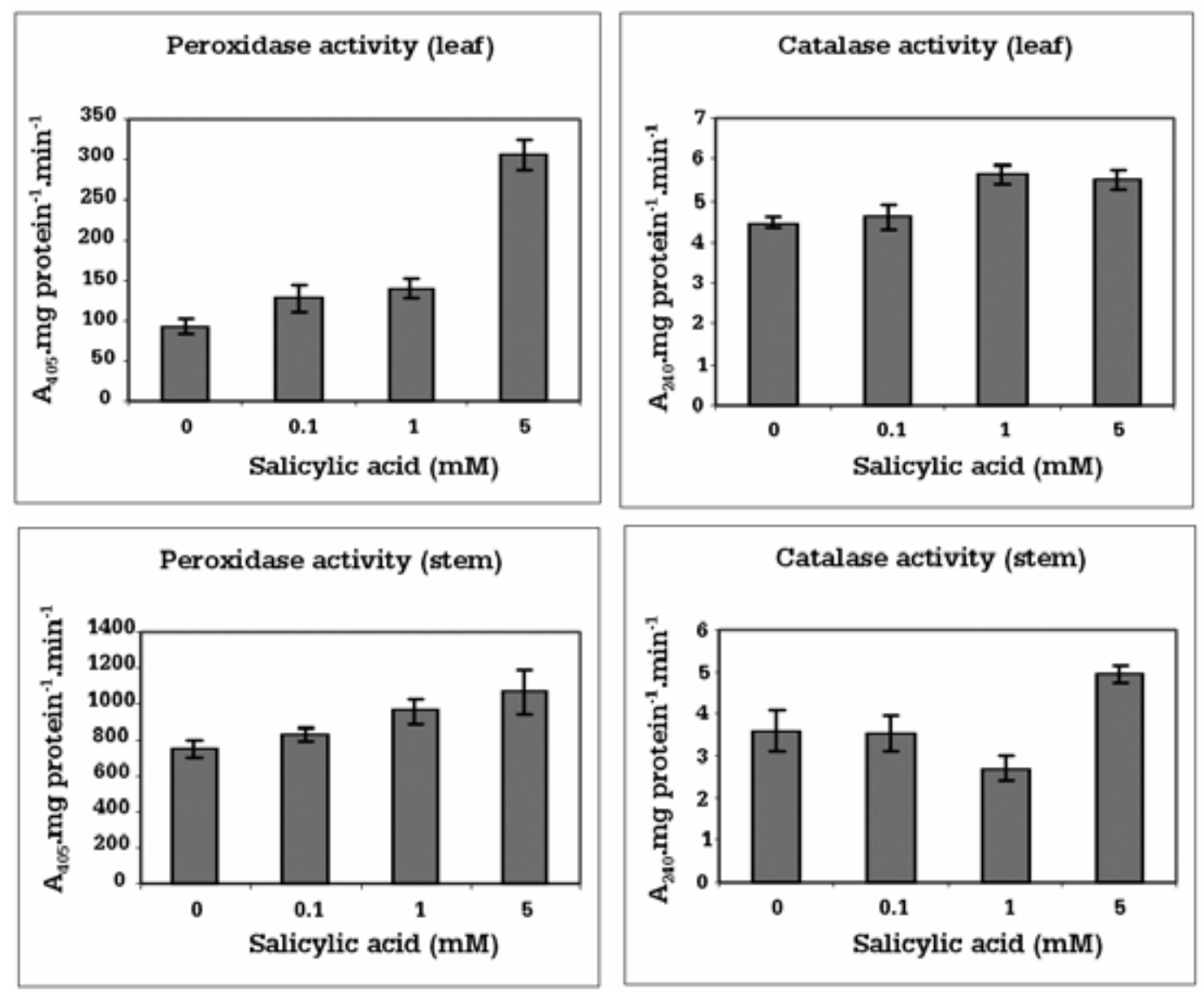

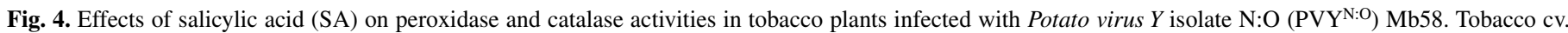

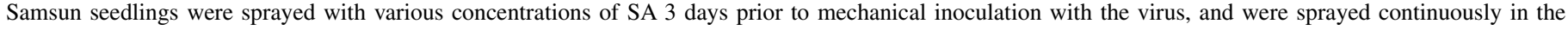

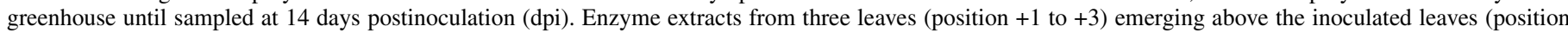

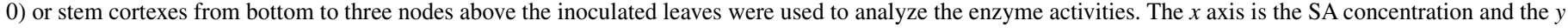

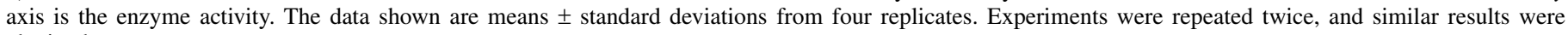
obtained. 
severity (Table 1), suggesting that the suppression of PVY-induced symptoms is mediated by SA and is ethylene-independent. Similar observations and mechanisms have been reported in several pathogen-host systems $(18,20,45)$. In Arabidopsis, activation of SA-mediated SAR results in efficient protection against Turnip crinkle virus (TCV), whereas ethylene-dependent induced systemic resistance (ISR) offers no protection against the virus
(45). It is possible that SA-dependent and ethylene-independent SAR is widely used in plants against viruses.

SA retarded the symptom initiation in stems by 1 to 2 days. Similar to the SA-mediated resistance against TMV, PVX, and CMV in tobacco, in which delayed symptoms are accompanied by reduced level of virus $(27,32)$, SA delayed PVY accumulation at the incubation stage (Fig. 3), suggesting that symptom develop-
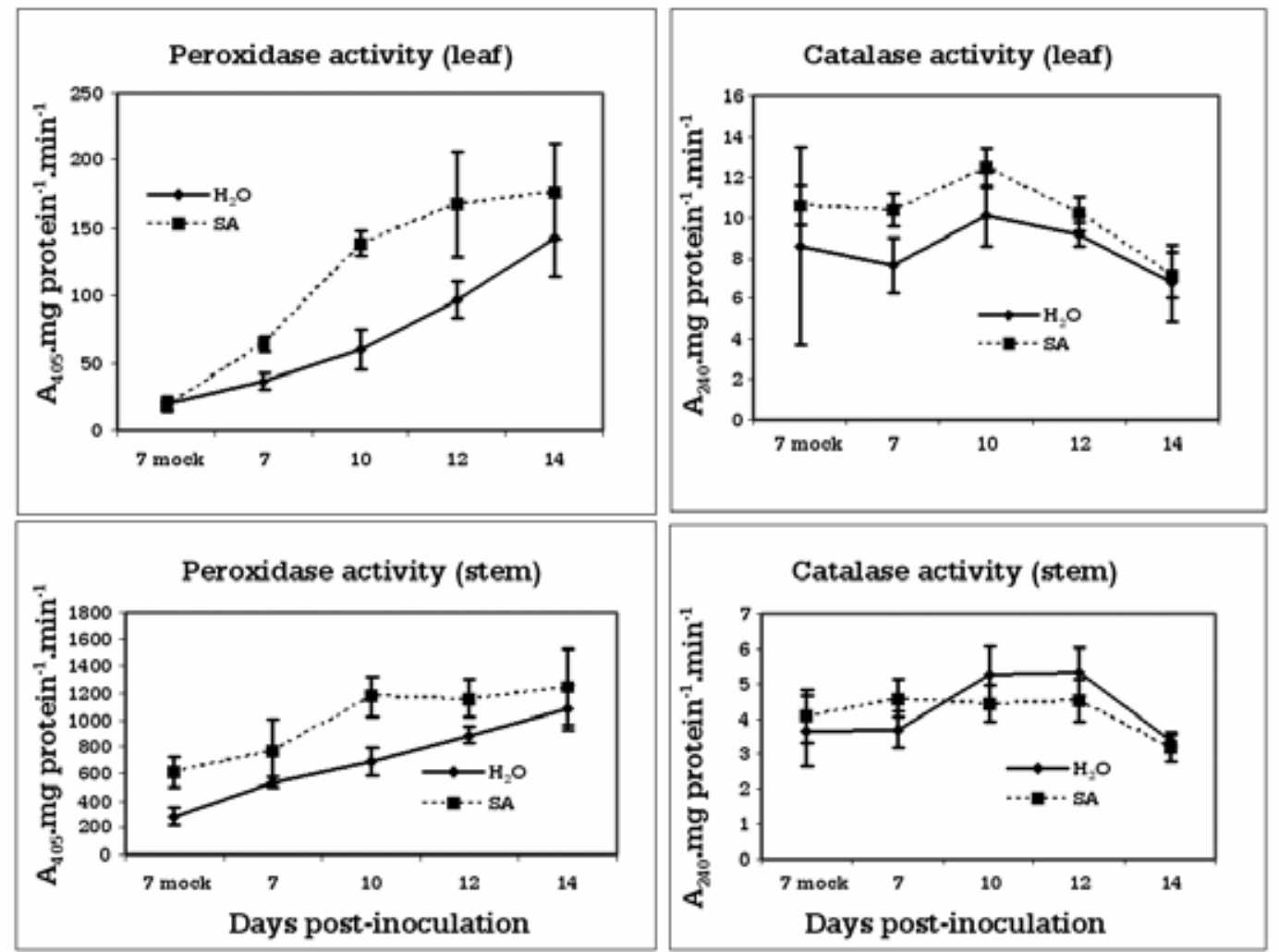

Fig. 5. Dynamics of peroxidase and catalase activities during the rapid symptom-progress stage in tobacco plants infected with Potato virus $Y$ isolate $\mathrm{N}$ : $\mathrm{O}$ $\left(\mathrm{PVY}^{\mathrm{N}: \mathrm{O}}\right) \mathrm{Mb} 58$. Tobacco cv. Samsun seedlings were sprayed with $\mathrm{H}_{2} \mathrm{O}$ or $1 \mathrm{mM}$ salicylic acid (SA) 3 days prior to mechanical inoculation with the virus or mock, and were sprayed continuously in the greenhouse until sampled. Enzyme activities of peroxidase and catalase in leaf and stem cortex tissues were measured at 7 to 14 days postinoculation. Enzyme extracts from three leaves (position +1 to +3 ) emerging above the inoculated leaves (position 0 ) or stem cortexes from bottom to three nodes above the inoculated leaves were used to analyze the enzyme activities. The data shown are means \pm standard deviations from four replicates. Experiments were repeated twice, and similar results were obtained.

Leaf

\begin{tabular}{c}
\hline $\mathrm{H}_{2} \mathrm{O}$ \\
$\mathrm{SA}$ \\
\hline
\end{tabular}

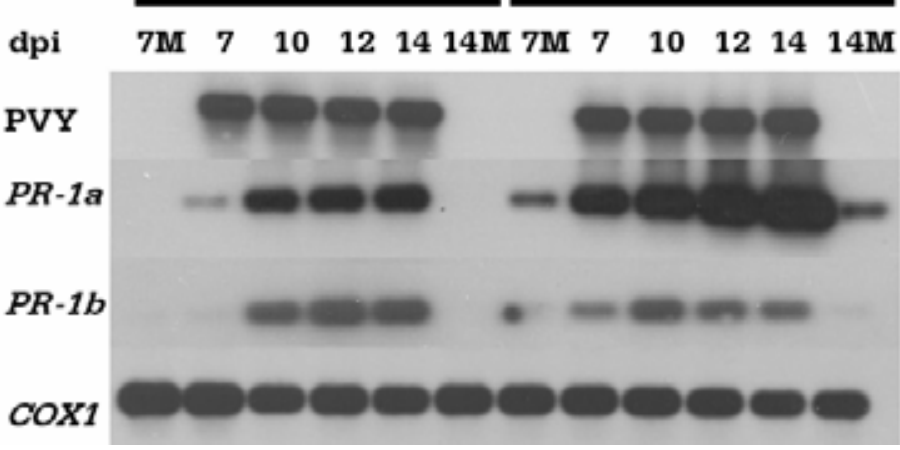

Stem

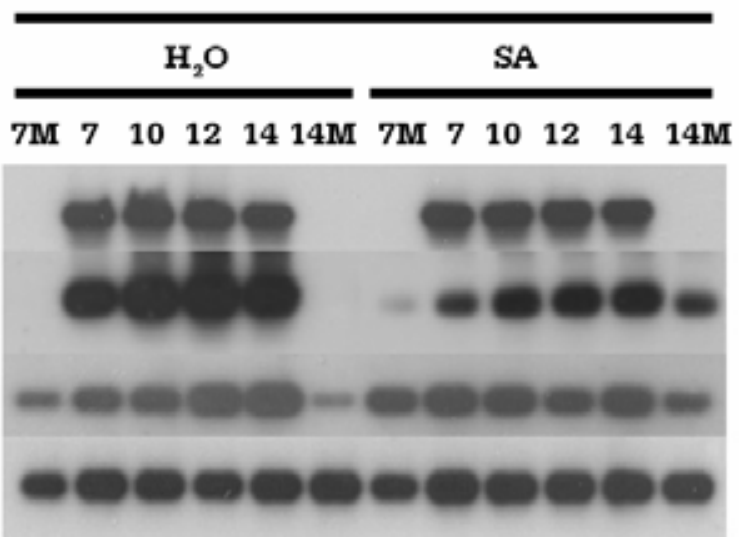

Fig. 6. Dynamics of pathogenesis-related (PR) gene expression during the rapid symptom-progress stage in tobacco plants infected with Potato virus $Y$ isolate $\mathrm{N}$ : $\mathrm{O}$ $\left(\mathrm{PVY}^{\mathrm{N}: \mathrm{O}}\right) \mathrm{Mb} 58$. Tobacco cv. Samsun seedlings were sprayed with $\mathrm{H}_{2} \mathrm{O}$ or $1 \mathrm{mM}$ salicylic acid (SA) 3 days prior to mechanical inoculation with the virus or mock (M), and were sprayed continuously in the greenhouse until sampled at 7,10,12, and 14 days postinoculation (dpi). RNA from three leaves (position +1 to +3 ) emerging above the inoculated leaves (position 0) or stem cortex tissue from bottom to three nodes above the inoculated leaves was used to analyze the PR gene expression. Duplex semiquantitative reverse transcription-polymerase chain reactions (RT-PCR) including the primer pairs targeting the cytochrome c oxidase subunit I (COX1) and the target gene were performed. Hybridization with the corresponding probes was performed after gel electrophoresis and blotting. Data shown were from 15 cycles of PCR with one representing COX1. The experiments were repeated twice, and similar results were obtained. 
ment and PVY replication/accumulation are closely related. The reduced necrotic symptoms in the stems of SA-treated plants were at least partially attributed to the inhibitory effects of SA on PVY replication/transportation. Unlike the TMV- and CMV-tobacco systems where SA exhibits prolonged inhibitory effects on accumulation of the viruses $(27,32)$, exogenous SA only demonstrated temporary inhibitory effects on PVY accumulation. These results suggest that PVY may have a mechanism to evade SA-mediated suppression of its replication and/or movement. The observation that there is no correlation between SA basal level and PVY ${ }^{\text {NTN }}$ resistance and, moreover, PVY ${ }^{\mathrm{NTN}}$ infection results in elevated endogenous SA concentration in a susceptible potato cultivar (19) to some extent supports the evading hypothesis.

Elevated expression of PR genes and increased activity of ROSassociated enzymes are typical features of SAR $(10,37,43)$. This study also demonstrated that PR genes and ROS-associated enzymes are correlated with SA-mediated suppression of PVY ${ }^{\mathrm{N}: \mathrm{O}}$ induced systemic development of symptoms in tobacco plants. SA elevated POX activity and $P R-1 a$ and $P R-1 b$ expression in mockinoculated plants and/or in PVY-infected plants during the course of virus-plant interaction at the rapid symptom-progress stage (Figs. 5 and 6), despite the fact that PR-1 proteins may not play a role in SAR against viruses (4). It is also interesting to note that, at the rapid symptom-progress stage, POX activity and $P R-1 a$ and $P R-1 b$ expression increased as the virus disease and systemic symptoms progressed. A set of $\mathrm{PR}$ genes, including $P R-1$, are elicited in susceptible Arabidopsis plants by several viruses including Turnip mosaic virus, a member of the genus Potyvirus (48). Plum pox virus, another potyvirus, also demonstrates its ability to enhance the abundance of $P R-1$ transcript in leaves of susceptible peach plants (46). Given the fact that PVY ${ }^{\mathrm{NTN}}$ can induce SA in susceptible potato plants (19), it is reasonable to speculate that the systemic infection of susceptible tobacco plants by $\mathrm{PVY}^{\mathrm{N}: \mathrm{O}}$ might have induced the endogenous $\mathrm{SA}$, which in turn might have resulted in the induction of $P R-1$ genes and POX. It does not, however, rule out the possibility that uncharacterized signaling pathways may be responsible for the regulation of PR genes in plants as suggested elsewhere $(46,48)$.

In summary, this work demonstrates that SA-mediated and ethylene-independent SAR plays an important role in suppression of $\mathrm{PVY}^{\mathrm{N}: \mathrm{O}}$-elicited necrotic symptoms in stems of tobacco plants. Given the complexity of PVY and PVY-host interactions as evidenced in this study as well as other studies $(3,8,14,16,17,19$, 30,31 ), further research is needed to elucidate the mechanism(s) involved in SA-mediated resistance against the virus as well as the partial recovery and symptom-shifting phenomena in susceptible plants after systemic infection with the virus.

\section{ACKNOWLEDGMENTS}

I thank T. Molen for excellent technical assistance; K. Corey for initial greenhouse work and symptom observation; and H. Tai for critically reviewing the manuscript prior to submission.

\section{LITERATURE CITED}

1. Antoniw, J. F., and White, R. F. 1980. The effects of aspirin and polyacrylic acid on soluble leaf proteins and resistance to virus infection in five cultivars of tobacco. Phytopathol. Z. 99:331-341.

2. Bradford, M. M. 1976. A rapid and sensitive method for the quantitation of microgram quantities of protein utilizing the principle of protein-dye binding. Anal. Biochem. 72:248-254.

3. Brandle, J. E., Stobbs, L. W., and Gleddie, S. 1995. Resistance to a necrotic strain of potato virus $\mathrm{Y}$ among Nicotiana species, somatic hybrids, and tobacco cultivars. Plant Dis. 79:152-154.

4. Carr, J. P., Beachy, R. N., and Klessig, D. F. 1989. Are the PR1 proteins of tobacco involved in genetically engineered resistance to TMV? Virology 169:470-473.

5. Chen, Z., Malamy, J., Henning, J., Conrath, U., Sanchez-Casas, P., Silva, H., Ricigliano, J., and Klessig, D. F. 1995. Induction, modification and transduction of salicylic acid signals in plant defense responses. Proc. Natl. Acad. Sci. USA 92:4134-4137.

6. Chivasa, S., and Carr, J. P. 1998. Cyanide restores N gene-mediated resistance to tobacco mosaic virus in transgenic tobacco expressing salicylic acid hydroxylase. Plant Cell 10:1489-1498.

7. Chivasa, S., Murphy, A. M., Naylor, M., and Carr, J. P. 1997. Salicylic acid interferes with tobacco mosaic virus replication via a novel salicylhydroxamic acid-sensitive mechanism. Plant Cell 9:547-557.

8. Chrzanowska, M. 1991. New isolates of the necrotic strain of Potato virus $\mathrm{Y}\left(\mathrm{PVY}^{\mathrm{N}}\right)$ found recently in Poland. Potato Res. 34:179-182.

9. Clarke, J. D., Volko, S. M., Ledford, H., Ausubel, F. M., and Dong, X. 2000. Roles of salicylic acid, jasmonic acid, and ethylene in cpr-induced resistance in Arabidopsis. Plant Cell 12:2175-2190.

10. Durrant, W. E., and Dong, X. 2004. Systemic acquired resistance. Ann. Rev. Phytopathol. 42:185-209.

11. Fellers, J. P., Collins, G. B., and Hunt, A. G. 1998. The NIa-proteinase of different plant potyviruses provides specific resistance to viral infection. Crop Sci. 38:1309-1319.

12. Fofana, B., Benhamou, N., McNally, D. J., Labbé, C., Séguin, A., and Bélanger, R. R. 2005. Suppression of induced resistance in cucumber through disruption of the flavonoid pathway. Phytopathology 95:114-123.

13. Fraser, R. S. S. 1992. The genetics of plant-virus interactions: Implications for plant breeding. Euphytica 63:175-185.

14. Glais, L., Tribodet, M., and Kerlan, C. 2002. Genomic variability in Potato potyvirus $Y$ (PVY): Evidence that $\mathrm{PVY}^{\mathrm{N}} \mathrm{W}$ and $\mathrm{PVY}^{\mathrm{NTN}}$ variants are single to multiple recombinants between $\mathrm{PVY}^{\mathrm{O}}$ and $\mathrm{PVY}^{\mathrm{N}}$ isolates. Arch. Virol. 147:363-378.

15. Havir, E. A., and McHale, N. A. 1987. Biochemical and developmental characterization of multiple form of catalase in tobacco leaves. Plant Physiol. 84:450-455.

16. Herbers, K., Meuwly, P., Frommer, W. B., Métraux, J. P., and Sonnewald, U. 1996. Systemic acquired resistance mediated by the ectopic expression of invertase: Possible hexose sensing in the secretory pathway. Plant Cell 8:793-803.

17. Herbers, K., Takahata, Y., Melzer, M., Mock, H.-P., Hajirezaei, M., and Sonnewald, U. 2000. Regulation of carbohydrate partitioning during the interaction of potato virus $Y$ with tobacco. Mol. Plant Pathol. 1:51-59.

18. Kachroo, P., Yoshioka, K., Shah, J., Dooner, H. K., and Klessig, D. F. 2000. Resistance to turnip crinkle virus in Arabidopsis is regulated by two host genes and is salicylic acid dependent but NPR1, ethylene, and jasmonate independent. Plant Cell 12:677-690.

19. Krečič-Stres, H., Vučak, C., Ravnikar, M., and Kovač, M. 2005. Systemic Potato virus $Y^{\text {NTN }}$ infection and levels of salicylic and gentisic acids in different potato genotypes. Plant Pathol. 54:441-447.

20. Lawton, K. A., Potter, S. L., Uknes, S., and Ryals, J. 1994. Acquired resistance signal transduction in Arabidopsis is ethylene independent. Plant Cell 6:581-588.

21. MacDiarmid, R. 2005. RNA silencing in productive virus infections. Ann. Rev. Phytopathol. 43:523-544.

22. Masuta, C., Nishimura, M., Morishita, H., and Hataya, T. 1999. A single amino acid change in viral genome-associated protein of potato virus $\mathrm{Y}$ correlates with resistance breaking in 'Virgin A Mutant' tobacco. Phytopathology 89:118-123.

23. Mayers, C. N., Lee, K.-C., Moore, C. A., Wong, S.-M., and Carr, J. P. 2005. Salicylic acid-induced resistance to Cucumber mosaic virus in squash and Arabidopsis thaliana: Contrasting mechanisms of induction and antiviral action. Mol. Plant-Microbe Interact. 18:428-434.

24. Mohapatra, S. S., Poole, R. J., and Dhindsa, R. S. 1987. Changes in protein patterns and translatable messenger RNA populations during cold acclimation of alfalfa. Plant Physiol. 84:1172-1176.

25. Murphy, A. M., and Carr, J. P. 2002. Salicylic acid has cell-specific effects on Tobacco mosaic virus replication and cell-to-cell movement. Plant Physiol. 128:552-563.

26. Murphy, A. M., Chivasa, S., Singh, D. P., and Carr, J. P. 1999. Salicylic acid-induced resistance to viruses and other pathogens: A parting of the ways? Trends Plant Sci. 4:155-160.

27. Naylor, M., Murphy, A. M., Berry, J. O., and Carr, J. P. 1998. Salicylic acid can induce resistance to plant virus movement. Mol. Plant-Microbe Interact. 11:860-868.

28. Neill, S. J., Desikan, R., Clarke, A., Hurst, R. D., and Hancock, J. T. 2002. Hydrogen peroxide and nitric oxide as signaling molecules in plants. J. Exp. Bot. 53:1237-1247.

29. Nie, X., and Singh, R. P. 2001. Differential accumulation of Potato virus $A$ and expression of pathogenesis-related genes in resistant potato $\mathrm{cv}$. Shepody upon graft inoculation. Phytopathology 91:197-203.

30. Nie, X., Singh, R. P., and Singh, M. 2004. Molecular and pathological characterization of $\mathrm{N}: \mathrm{O}$ isolates of the Potato virus $Y$ from Manitoba, Canada. Can. J. Plant Pathol. 26:573-583.

31. Nie, X., Singh, R. P., and Tai, G. C. C. 2002. Molecular characterization and expression analysis of 1-aminocyclopropane-1-carboxylate oxidase 
homologs from potato under abiotic and biotic stresses. Genome 45: 905-913.

32. Ordog, S. H., Higgins, V. J., and Vanlerberghe, G. C. 2002. Mitochondrial alternative oxidase is not a critical component of plant viral resistance but may play a role in the hypersensitive response. Plant Physiol. 129:18581865.

33. Parrella, G., Ruffel, S., Moretti, A., Morel, C., Palloix, A., and Caranta, C. 2002. Recessive resistance genes against potyviruses are localized in colinear genomic regions of the tomato (Lycopersicon spp.) and pepper (Capsicum spp.) genomes. Theor. Appl. Genet. 105:855-861.

34. Piche, L. M., Singh, R. P., Nie, X., and Gudmestad, N. C. 2004. Diversity among Potato virus $Y$ isolates obtained from potatoes grown in the United States. Phytopathology 94:1368-1375.

35. Ratcliff, F., Harrison, B. D., and Baulcombe, D. C. 1997. A similarity between viral defense and gene silencing in plants. Science 276:15581560 .

36. Ratcliff, F. G., MacFarlane, S. A., and Baulcombe, D. C. 1999. Gene silencing without DNA: RNA-mediated cross-protection between viruses. Plant Cell 11:1207-1216.

37. Shah, J. 2003. The salicylic acid loop in plant defense. Curr. Opin. Plant Biol. 6:365-371.

38. Shetty, N. P., Kristensen, B. K., Newman, M.-A., Møller, K., Gregersen, P. L., and Jørgensen, H. J. L. 2003. Association of hydrogen peroxide with restriction of Septoria tritici in resistant wheat. Physiol. Mol. Plant Pathol. 62:333-346.

39. Shoresh, M., Yedidia, I., and Chet, I. 2005. Involvement of jasmonic acid/ethylene signaling pathway in the systemic resistance induced in cucumber by Trichoderma asperellum T203. Phytopathology 95:76-84.

40. Shukla, D. D., Ward, C. W., and Brunt, A. A. 1994. The Potyviridae. CAB
International, Cambridge University Press, Cambridge.

41. Singh, R. P., Kurz, J., and Boiteau, G. 1996. Detection of stylet-borne and circulative potato viruses in aphids by duplex reverse transcription polymerase chain reaction. J. Virol. Methods 59:189-196.

42. Singh, R. P., McLaren, D. L., Nie, X., and Singh, M. 2003. Possible escape of a recombinant isolate of Potato virus $Y$ by serological indexing and methods of its detection. Plant Dis. 87:679-685.

43. Sticher, L., Mauch-Mani, B., and Métraux, J. P. 1997. Systemic acquired resistance. Annu. Rev. Phytopathol. 35:235-270.

44. Thomma, B. P. H. J., Eggermont, K., Tierens, K. F. M.-J., and Broekaert, W. F. 1999. Requirement of functional ethylene-insensitive 2 gene for efficient resistance of Arabidopsis to infection by Botrytis cinerea. Plant Physiol. 121:1093-1101.

45. Ton, J., Van Pelt, J. A., Van Loon, L. C., and Pieterse, C. M. J. 2002. Differential effectiveness of salicylate-dependent and jasmonate/ethylenedependent induced resistance in Arabidopsis. Mol. Plant-Microbe Interact. 15:27-34.

46. Wang, A., Chapman, P., Chen, L., Stobbs, L. W., Brown, D. C. W., and Brandle, J. E. 2005. A comparative survey, by expressed sequence tag analysis, of genes expressed in peach leaves infected with Plum pox virus (PPV) and free from PPV. Can. J. Plant Pathol. 27:410-419.

47. White, R. F., Antoniw, J. F., Carr, J. P., and Woods, R. D. 1983. The effects of aspirin and polyacrylic acid on the multiplication and spread of TMV in different cultivars of tobacco with and without the $\mathrm{N}$-gene. Phytopathol. Z. 107:224-232.

48. Whitham, S. A., Quan, S., Chang, H.-S., Cooper, B., Estes, B., Zhu, T., Wang, X., and Hou, Y.-M. 2003. Diverse RNA viruses elicit the expression of common sets of genes in susceptible Arabidopsis thaliana plants. Plant J. 33:271-283. 